\title{
Isokinetic assessment of extensor and flexor muscles of the knee joint in patients after anterior cruciate ligament reconstruction treated by the LARS method - preliminary report
}

\section{Ocena izokinetyczna mięśni prostowników i zginaczy stawu kolanowego u pacjentów po rekonstrukcji więzadła krzyżowego przedniego leczonych metodą LARS - doniesienie wstępne}

\author{
Jędrzej Płocki1 ${ }^{1,2}$, Ireneusz Kotela ${ }^{3,4}$, Dominik Pikuła1 ${ }^{1}$, Agnieszka Bejer ${ }^{1,2}$, Mirosław Probachta ${ }^{1,5}$, Andrzej Kotela \\ ${ }^{1}$ Department of Rehabilitation, Holy Family Specialist Hospital, Rudna Mała, Poland \\ Head of the Department: Bożena Sałata MD \\ ${ }^{2}$ Chair of Physiotherapy, Faculty of Medicine, University of Information Technology and Management with Seat, Rzeszow, Poland \\ Head of the Chair: Helena Bartyzel-Lewforowicz PhD \\ ${ }^{3}$ Department of Orthopaedics and Traumatology, Clinic of Orthopaedics and Traumatology, Central Clinical Hospital of the Ministry \\ of Internal Affairs, Warsaw, Poland \\ Head of the Department: Prof. Ireneusz Kotela MD, PhD \\ ${ }^{4}$ Department of Rehabilitation in Disease of the Locomotor, Institute of Physiotherapy, Faculty of Health Sciences, Jan Kochanowski \\ University, Kielce, Poland \\ Head of the Department: Prof. Ireneusz Kotela MD, PhD \\ ${ }^{5}$ Department of Medicine, Institute of Physiotherapy, Faculty of Medicine, University of Rzeszow, Rzeszow, Poland \\ Head of the Department: Prof. Anna Wilmowska-Pietruszyska PhD \\ ${ }^{6}$ Department of Orthopaedics and Traumatology, $1^{\text {st }}$ Faculty of Medicine, Medical University of Warsaw, Warsaw, Poland \\ Head of the Department: Prof. Ireneusz Kotela MD, PhD
}

Key words: anterior cruciate ligament reconstruction, LARS method, isokinetic.

Słowa kluczowe: rekonstrukcja więzadła krzyżowego przedniego, metoda LARS, izokinetyka.

\begin{abstract}
Introduction: Anterior cruciate ligament (ACL) reconstruction is aimed at restoration of the function of the knee joint. Aim of the research: Isokinetic assessment of the extensor and flexor muscles of the knee joint in patients treated using the LARS method within the period of 3-5 years after surgery, compared to healthy individuals.

Material and methods: The group consisted of 40 patients. Each group included 20 persons: study group and control group. The study group included patients who had undergone LARS surgery. The control group comprised healthy individuals. The patients completed a questionnaire containing the respondents' particulars. The second part of the study covered isokinetic tests performed using the Biodex System 4.

Results: No statistically significant differences were found between the values of the isokinetic parameters for the operated extremity in the study group, compared to the results obtained in the control group, for the total number of subjects in the study. Statistically significant differences were observed between the flexors peak torque/BW $(p=0.001)$ and extensors peak torque/BW $(p=0.012)$ for operated and non-operated lower extremities.

Conclusions: Despite muscle strength deficit in the operated limb in patients treated using the LARS method, the strength of flexors and extensors remained on the level of the healthy population examined. The duration of rehabilitation was too short to assess the effect of the type of rehabilitation on muscle strength parameters of the knee joint flexors and extensors. In order to determine the effect of the selected variables on muscle strength parameters, studies should be conducted in a larger population sample.
\end{abstract}

\section{Streszczenie}

Wprowadzenie: Rekonstrukcja więzadła krzyżowego przedniego (ACL) ma na celu przywrócenie funkcji stawu kolanowego. Cel pracy: Ocena izokinetyczna mięśni prostowników i zginaczy stawu kolanowego pacjentów leczonych metodą LARS w ciągu 3-5 lat od operacji w porównaniu z grupą zdrowych osób. 


\begin{abstract}
Materiał i metody: Do badania zakwalifikowano łącznie 40 osób. Badani tworzyli dwie równoliczne grupy po 20 osób - grupę badaną i grupę kontrolną. W grupie badanej znajdowały się osoby operowane metodą LARS, natomiast w grupie kontrolnej - osoby zdrowe. Pacjenci zostali poddani badaniu ankietowemu, które dotyczyło danych metrykalnych. Druga część badania obejmowała testy izokinetyczne na stanowisku Biodex 4 .

Wyniki: Stwierdzono brak istotnych statystycznie różnic pomiędzy wartościami parametrów izokinetycznych dla operowanej kończyny w grupie badanej względem wyników uzyskanych w grupie kontrolnej dla ogółu badanych. Wykazano obecność istotnych statystycznie różnic między wartościami parametrów zginacze peak torqe/bw $(p=0,001)$ oraz prostowniki peak torque/bw $(p=0,012)$ dla kończyn dolnych operowanych i nieoperowanych.

Wnioski: Pomimo deficytu siły mięśniowej w kończynie operowanej u pacjentów leczonych metodą LARS siła zginaczy i prostowników jest na poziomie zbadanej populacji zdrowej. Czas trwania rehabilitacji był zbyt krótki, aby ocenić wpływ jej rodzaju na parametry siłowe mięśni zginaczy i prostowników stawu kolanowego. W celu określenia wpływu wybranych zmiennych na parametry siłowe mięśni należy przeprowadzić badanie na większej próbie.
\end{abstract}

\section{Introduction}

Arthroscopic reconstruction of the anterior cruciate ligament (ACL) is the technique of choice applied in the treatment of injury to the ligamentous apparatus of the knee joint. In Poland, the first knee arthroscopy was performed in 1974, in the Orthopaedic Clinic in Warsaw, by Kuś and Salomon [1]. The sole reconstruction procedure has evolved within the last 30 years. The best solutions were sought that would allow the regaining of full efficiency within the shortest time possible, enabling the return to work and social life, as well as full physical activity [2-4]. The methods using the autologous and allogeneic transplants provide the return to full efficiency and physical activity within the period of 6-9 months after the surgical procedure [5-7]. Synthetic materials, which were introduced as early as in the 1970s as a substitute of biological tissue, decisively prevail considering the possibility of enabling a quick return to physical activity [8]. At present, the polyethylene ligament LARS (Ligament Augmentation and Reconstruction System) is applied for reconstruction. The LARS prosthetic ligament was designed by the French surgeon Jaques Phillipe Laboureau from Dijon. Initially, it was applied for the reconstruction of the posterior cruciate ligament (PCL), and its use was subsequently expanded [9]. Its special construction provides excellent durability when subjected to stretching (1500-4700 N), and the special porous structure of the weave increases the resiliency of the ligament, which decreases the wear between fibres, and prevents the desquamation of the material and its degradation [9]. The return to physical activity takes place within the period of 3-4 months after surgical procedure [10].

The restoration of muscle strength [11] and proprioception [12] is important for the normal functioning of the knee joint. A physiotherapy programme that covers the restoration of the normal kinematics of the joint, proprioception, and muscle strength is an important element exerting an effect on the quality of functioning of the joint while returning to physical and occupational activity. Muscles constitute an important stabilising element of the joint in motion and at rest [13]. The role of the group of the ischiotibial muscles seems to be important, which is responsible for inhibition of the anterior tibial transition protecting the ligament against an excessive load during motion [14]. Researchers have observed muscle strength deficits concerning both extensors and flexors of the knee joint many years after surgery. These deficits occur mainly in the operated limbs; however, they may also concern healthy limbs [11]. The correct restoration of muscle strength between antagonistic muscle groups, as well as the normal muscle balance between the healthy limb and the operated limb, decrease the risk of repeated injuries to the knee joint $[15,16]$.

At present, dynamometers are used for objective measurements of muscle strength and other characteristics of muscle functions. Accordingly, they may be applied to perform measurements of the isotonic, isometric, and isokinetic work [17]. The advantages of isokinetic assessment and training are, among others, safety due to the resistance adjusted to the capabilities of a patient, objectivisation of the results obtained, which may be referred to the standards, and high validity, reliability, and repeatability of the isokinetic test [18].

\section{Aim of the research}

The objective of the study was isokinetic assessment of the extensor and flexor muscles of the knee joint in patients treated using the LARS method within the period of 3-5 years after surgery, compared to a group of healthy individuals who had not undergone any surgical procedures concerning the knee joint. In addition, the study was aimed at determining the effect on the muscle strength parameters of time elapsed between injury and surgery, and the effect of duration, type of the rehabilitation conducted, and patients' age on muscle strength.

\section{Material and methods}

A total of 40 subjects were qualified for the study two equally numerous groups of 20 individuals each: the study group and the control group. The study group included patients who had undergone surgery using the LARS ligament, while the control group consisted of healthy individuals (Table 1). 
The mean age of patients who had undergone surgery using the LARS ligament in our own study was 33.6 years, while that of healthy individuals was 33.1 years. The youngest subjects in both groups were aged 27 years, whereas the oldest was 40 years. All the patients in the study group underwent surgery in the Holy Family Specialist Hospital in Rudna Mala.

The patients completed a questionnaire containing respondents' particulars and clinical data: age, gender, type of graft - confirmed by medical records, time between injury and surgery, period between surgery and examination, type of rehabilitation conducted, and its duration based on medical records.

In the second part of the study, muscle strength tests were performed on a Biodex System 4 isokinetic dynamometer. The position assumed by the patient in the chair during the examination, as well as the settings of the dynamometer with the attachment, was in accordance with standards specified by the producer. During the examination, the patient was held in a stabilised position by three stabilisation belts. Each person in the study performed two trials consisting of five repetitions. Measurements for the needs of the study were performed for angular velocity $60^{\circ} \mathrm{s}$ and the cycle of concentric work of extensor and flexor muscles (con/con). Before undertaking the trial, each patient performed a 5-minute warm-up on a cycloergometer. During the test, the patients were mobilised for the greatest possible engagement in the physical activity performed [17].

All patients participating in the study were informed concerning the objective and method of conducting the study, and expressed their consent for participation.

\section{Statistical analysis}

Statistical analysis of the collected material was performed using the statistical package Statistica 10.0 StatSoft. The variables were analysed by means of both parametric and non-parametric tests. The selection of a parametric test was conditioned by satisfying its basic assumption, i.e. conformity of the distribution of the examined variables with the normal distri-
Table 1. Division of subjects into groups

\begin{tabular}{|lcc|}
\hline Division into groups & $\boldsymbol{N}$ & $\%$ \\
$\begin{array}{l}\text { Study group - patients operated on } \\
\text { using the LARS ligament }\end{array}$ & 20 & 50 \\
Control group - healthy individuals & 20 & 50 \\
Total & 40 & 100 \\
\hline
\end{tabular}

$n$-number of observations. Source: own study

bution, and their verification using the Shapiro-Wilk test. For all the numerical variables, descriptive statistics were calculated: mean, median, minimum, maximum, and standard deviation.

The differences between measurements performed twice in the same persons were investigated using the $t$-Student test for dependent samples, or by the non-parametric Wilcoxon matched pairs test. The differences between two independent groups were evaluated using $t$-Student test for independent samples, or by the non-parametric Mann-Whitney $U$ test. The correlation between two normally distributed variables was determined by means of Pearson linear correlation coefficient, and for variables that did not satisfy the criterion of normality of distribution Spearman's rank correlation coefficient was calculated. The $p$-values $<0.05$ were considered statistically significant.

\section{Results}

No statistically significant differences were found between the values of isokinetic parameters for the operated limbs in the study group, compared to the results obtained in the control group (based on the mean values for the right and left limbs) for the total number of subjects in the study (Table 2).

During analysis, the results of isokinetic parameters in the study group were compared for the operated and non-operated limbs, in order to determine the restoration of muscle strength.

Statistically significant differences were observed between the values of the parameters flexors peak torque/BW $(p=0.001)$ and extensors peak torque/BW

Table 2. Comparison of results of isokinetic parameters for the total number of study participants

\begin{tabular}{|c|c|c|c|c|c|c|c|c|c|c|c|c|}
\hline \multirow[t]{2}{*}{ CON-CON 60} & \multicolumn{5}{|c|}{ Study group } & \multicolumn{5}{|c|}{ Control group } & \multirow[t]{2}{*}{$t / Z$} & \multirow[t]{2}{*}{$P$-value } \\
\hline & $\bar{x}$ & $\mathrm{Me}$ & Min. & Max. & SD & $\bar{x}$ & $\mathrm{Me}$ & Min. & Max. & SD & & \\
\hline $\begin{array}{l}\text { FLEXORS PEAK } \\
\text { TORQUE/BW }\end{array}$ & 73.9 & 73.6 & 12.6 & 116.8 & 25.1 & 88.4 & 91.6 & 38.4 & 138.1 & 27.5 & -1.75 & 0.089 \\
\hline $\begin{array}{l}\text { EXTENSORS PEAK } \\
\text { TORQUE/BW }\end{array}$ & 163.5 & 162.8 & 64.6 & 347.1 & 73.6 & 185.7 & 184.5 & 85.6 & 263.3 & 52.9 & -1.09 & 0.281 \\
\hline $\begin{array}{l}\text { AGON/ANTAG } \\
\text { RATIO }\end{array}$ & 49.4 & 47.0 & 16.5 & 83.5 & 18.0 & 48.7 & 50.4 & 15.7 & 70.7 & 11.2 & -0.33 & 0.735 \\
\hline
\end{tabular}

$\bar{x}$ - arithmetic mean, Me-median, min. - minimum, max. - maximum, SD - standard deviation, $t$ - value of $t$-Student test for independent samples/Z-value for Mann-Whitney $U$ test, $p$-level of probability. Source: own study. 
$(p=0.012)$ for the operated and non-operated lower limbs. Higher values of these variables were noted in the case of non-operated lower limbs. The value of the agon/antag ratio parameter did not significantly differ in the two groups examined ( $p=0.779)$ (Table 3).

Analysis of the relationship between muscle strength and patient's age, and time between the performance of surgery and the examination, which remained within the period of 3-5 years, also did not show any statistically significant difference (Table 4).

Statistical differences were observed between the values of the parameters flexors peak torque/BW $(p=0.044)$ and extensors peak torque/BW ( $p=0.026)$ for the lower healthy extremities, when the time between injury and surgery was a maximum of 6 or at least 7 weeks (Table 5).
Higher values of both the above-mentioned parameters were observed among patients in whom the time between the surgery and examination was not longer than 6 weeks. The values of the remaining isokinetic parameters did not significantly differ between the subjects from the two groups. In the case of ACL reconstruction performed using the LARS ligament, the time between injury and surgery is especially important. The designers of the LARS method recommend its use within the shortest time possible after rupture, preferably up to 3 weeks after injury. The result obtained shows the relationship between the short period between injury and surgery, and muscle strength, in the non-operated limb. In order to correctly interpret the obtained result, it is necessary to perform analysis of statistical data collected in a larger population group.

Table 3. Comparison of results of isokinetic parameters in the study group for the operated and non-operated limbs

\begin{tabular}{|c|c|c|c|c|c|c|c|c|c|c|c|c|}
\hline \multirow[t]{2}{*}{ CON-CON 60} & \multicolumn{5}{|c|}{ Study group - operated limbs } & \multicolumn{5}{|c|}{ Study group - non-operated limbs } & \multirow[t]{2}{*}{$t / Z$} & \multirow[t]{2}{*}{$P$-value } \\
\hline & $\bar{x}$ & Me & Min. & Max. & SD & $\bar{x}$ & Me & Min. & Max. & SD & & \\
\hline $\begin{array}{l}\text { FLEXORS PEAK } \\
\text { TORQUE/BW }\end{array}$ & 73.9 & 73.6 & 12.6 & 116.8 & 25.1 & 101.7 & 103.1 & 42.3 & 267.3 & 49.2 & 3.09 & 0.001 \\
\hline $\begin{array}{l}\text { EXTENSORS PEAK } \\
\text { TORQUE/BW }\end{array}$ & 163.5 & 162.8 & 64.6 & 347.1 & 73.6 & 199.5 & 208.9 & 69.0 & 324.2 & 64.8 & -2.74 & 0.012 \\
\hline $\begin{array}{l}\text { AGON/ANTAG } \\
\text { RATIO }\end{array}$ & 49.4 & 47.0 & 16.5 & 83.5 & 18.0 & 50.8 & 49.2 & 27.1 & 82.4 & 13.4 & 0.27 & 0.779 \\
\hline
\end{tabular}

$\bar{x}$ - arithmetic mean, Me - median, min. - minimum, max. - maximum, SD - standard deviation, $t$-value of $t$-Student test for independent samples/Z-value for Mann-Whitney U test, $p$-level of probability. Source: own study.

Table 4. Correlations between the result of isokinetic parameters and time between surgery and the examination, and age

\begin{tabular}{|lcc|}
\hline Pairs of variables & $r / R$ & $P$-value \\
FLEXORS TORQUE/BW OL vs. age & 0.19 & 0.416 \\
EXTENSORS PEAK TORQUE/BW OL vs. age & -0.01 & 0.944 \\
AGON/ANTAG RATIO OL vs. age & 0.29 & 0.212 \\
FLEXORS PEAK TORQUE/BW OL vs. time between surgery and examination & 0.20 & 0.389 \\
EXTENSORS PEAK TORQUE/BW OL vs. time between surgery and examination & 0.19 & 0.412 \\
AGON/ANTAG RATIO OL vs. time between surgery and examination & -0.08 & 0.714 \\
FLEXORS PEAK TORQUE/BW NOL vs. time between surgery and examination & 0.31 & 0.183 \\
EXTENSORS PEAK TORQUE/BW NOL vs. time between surgery and examination & 0.21 & 0.366 \\
AGON/ANTAG RATIO NOL vs. time between surgery and examination & 0.44 & 0.051 \\
FLEXORS PEAK TORQUE/BW NOL vs. age & -0.13 & 0.556 \\
EXTENSORS PEAK TORQUE/BW NOL vs. age & -0.07 & 0.765 \\
AGON/ANTAG RATIO NOL vs. age & 0.08 & 0.716 \\
\hline
\end{tabular}

$O L$ - operated limbs, NOL - non-operated limbs, $r / R$-value of Pearson linear correlation test/Spearman rank correlation, $p$ - level of probability. Source: own study. 
Table 5. Comparison of results of isokinetic parameters according to the time between injury and surgery

\begin{tabular}{|c|c|c|c|c|c|c|c|c|c|c|c|c|}
\hline \multirow[t]{2}{*}{ CON-CON 60} & \multicolumn{5}{|c|}{ Study group $\leq 6(8 ; 40.0 \%)$} & \multicolumn{5}{|c|}{ Study group $\geq 7(12 ; 60.0 \%)$} & \multirow[t]{2}{*}{$t / U$} & \multirow[t]{2}{*}{$P$-value } \\
\hline & $\bar{x}$ & Me & Min. & Max. & SD & $\bar{x}$ & Me & Min. & Max. & SD & & \\
\hline $\begin{array}{l}\text { FLEXORS PEAK } \\
\text { TORQUE/BW OL }\end{array}$ & 77.2 & 73.6 & 49.4 & 116.8 & 21.5 & 68.9 & 70.5 & 12.6 & 103.1 & 30.6 & 0.71 & 0.485 \\
\hline $\begin{array}{l}\text { EXTENSORS PEAK } \\
\text { TORQUE/BW OL }\end{array}$ & 183.1 & 177.8 & 103.2 & 347.1 & 75.8 & 134.1 & 118.1 & 64.6 & 235.3 & 63.6 & 1.51 & 0.149 \\
\hline $\begin{array}{l}\text { AGON/ANTAG } \\
\text { RATIO OL }\end{array}$ & 46.5 & 46.5 & 16.5 & 69.9 & 15.0 & 53.9 & 53.3 & 17.5 & 83.5 & 22.2 & -0.91 & 0.377 \\
\hline $\begin{array}{l}\text { FLEXORS PEAK } \\
\text { TORQUE/BW NOL }\end{array}$ & 117.1 & 107.0 & 79.2 & 267.3 & 49.9 & 78.7 & 59.0 & 42.3 & 145.2 & 40.5 & 0.00 & 0.044 \\
\hline $\begin{array}{l}\text { EXTENSORS PEAK } \\
\text { TORQUE/BW NOL }\end{array}$ & 225.1 & 221.6 & 157.2 & 324.2 & 43.1 & 161.1 & 137.2 & 69.0 & 263.2 & 75.2 & 2.43 & 0.026 \\
\hline $\begin{array}{l}\text { AGON/ANTAG } \\
\text { RATIO NOL }\end{array}$ & 51.1 & 49.2 & 38.4 & 82.4 & 12.3 & 50.4 & 49.0 & 27.1 & 81.6 & 15.7 & 1.00 & 0.088 \\
\hline
\end{tabular}

$O L$ - operated limbs, NOL - non-operated limbs, $\bar{x}$ - arithmetic mean, Me - median, min. - minimum, max. - maximum, SD - standard deviation, $t$-value of $t$-Student test for independent variables/U - value of Mann-Whitney $U$ test, $p$-level of probability. Source: own study.

The value of the agon/antag ratio\% parameter significantly differed for healthy lower extremities among persons who had undergone exclusively the procedures within the scope of physiotherapy, and among those in whom, as well as physiotherapeutic procedures, individual therapy was also applied $(p=0.035)$. Higher values of this parameter were also noted among individuals subjected exclusively to the procedures within the scope of physiotherapy. The values of the remaining isokinetic parameters did not significantly differ between the subjects from the two groups (Table 6).

The result of the agon/antag ratio\% parameter obtained in the healthy limbs in patients in whom exclusively physiotherapeutic procedures were applied was close to the model ratio between flexor muscle strength to extensors of the knee joint, and was $61.5 \%$. However, for the operated limb this indicator was $42 \%$. The imbalance of the muscle strength observed in this group of patients, which was $19.5 \%$, indicates the need for enhancement of strength of the knee joint flexors. In patients who used individual therapy and physiotherapy, the difference in the indicator agon/antag ratio $\%$ between the limbs was $4.5 \%$, which is the normal ratio of muscle strength.

No differences in muscle strength were found according to the duration of rehabilitation, with consideration of its duration up to 4 weeks and more than

Table 6. Comparison of results of isokinetic parameters according to the type of rehabilitation

\begin{tabular}{|c|c|c|c|c|c|c|c|c|c|c|c|c|}
\hline \multirow[t]{2}{*}{ CON-CON 60} & \multicolumn{5}{|c|}{$\begin{array}{l}\text { Study group - physiotherapy } \\
(5 ; 25.0 \%)\end{array}$} & \multicolumn{5}{|c|}{$\begin{array}{l}\text { Study group - physiotherapy + } \\
\text { individual therapy }(15 ; 75.0 \%)\end{array}$} & \multirow[t]{2}{*}{$t / U$} & \multirow[t]{2}{*}{$P$-value } \\
\hline & $\bar{x}$ & $\mathrm{Me}$ & Min. & Max. & SD & $\bar{x}$ & Me & Min. & Max. & SD & & \\
\hline $\begin{array}{l}\text { FLEXORS PEAK } \\
\text { TORQUE/BW OL }\end{array}$ & 68.5 & 79.2 & 12.6 & 103.9 & 37.9 & 75.7 & 72.1 & 49.4 & 116.8 & 20.8 & -0.54 & 0.596 \\
\hline $\begin{array}{l}\text { EXTENSORS PEAK } \\
\text { TORQUE/BW OL }\end{array}$ & 164.2 & 131.5 & 71.7 & 277.7 & 88.2 & 163.3 & 170.0 & 64.6 & 347.1 & 71.6 & 0.02 & 0.982 \\
\hline $\begin{array}{l}\text { AGON/ANTAG } \\
\text { RATIO OL }\end{array}$ & 42.0 & 37.4 & 17.5 & 74.5 & 21.0 & 51.9 & 47.3 & 16.5 & 83.5 & 17.0 & -1.07 & 0.297 \\
\hline $\begin{array}{l}\text { FLEXORS PEAK } \\
\text { TORQUE/BW NOL }\end{array}$ & 125.5 & 116.2 & 42.5 & 267.3 & 89.8 & 93.8 & 100.2 & 42.3 & 134.8 & 26.7 & 1.27 & 0.222 \\
\hline $\begin{array}{l}\text { EXTENSORS PEAK } \\
\text { TORQUE/BW NOL }\end{array}$ & 203.0 & 262.3 & 69.0 & 324.2 & 113.1 & 198.3 & 208.8 & 114.9 & 264.0 & 45.1 & 0.14 & 0.893 \\
\hline $\begin{array}{l}\text { AGON/ANTAG } \\
\text { RATIO NOL }\end{array}$ & 61.5 & 55.2 & 44.0 & 82.4 & 19.3 & 47.3 & 47.3 & 27.1 & 60.4 & 9.1 & 2.28 & 0.035 \\
\hline
\end{tabular}

OL - operated limbs, NOL - non-operated limbs, $\bar{x}$ - arithmetic mean, Me-median, min. - minimum, max. - maximum, SD - standard deviation, $t$ - value of $t$-Student test for independent variables/U - value of Mann-Whitney U test, $p$ - level of probability. Source: own study. 
Table 7. Comparison of the results of isokinetic parameters according to the duration of rehabilitation (in weeks)

\begin{tabular}{|c|c|c|c|c|c|c|c|c|c|c|c|c|}
\hline \multirow[t]{2}{*}{ CON-CON 60} & \multicolumn{5}{|c|}{ Study group $2-4(8 ; 40.0 \%)$} & \multicolumn{5}{|c|}{ Study group $\geq 5(12 ; 60.0 \%)$} & \multirow[t]{2}{*}{$t / U$} & \multirow[t]{2}{*}{$P$-value } \\
\hline & $\bar{x}$ & $\mathrm{Me}$ & Min. & Max. & SD & $\bar{x}$ & $\mathrm{Me}$ & Min. & Max. & SD & & \\
\hline $\begin{array}{l}\text { FLEXORS } \\
\text { TORQUE/BW OL }\end{array}$ & 65.2 & 67.3 & 12.6 & 103.9 & 26.0 & 79.7 & 83.2 & 49.0 & 116.8 & 23.8 & -1.29 & 0.215 \\
\hline $\begin{array}{l}\text { EXTENSORS PEAK } \\
\text { TORQUE/BW OL }\end{array}$ & 140.4 & 107.8 & 64.6 & 277.7 & 79.3 & 178.9 & 179.3 & 104.6 & 347.1 & 68.6 & -1.15 & 0.263 \\
\hline $\begin{array}{l}\text { AGON/ANTAG } \\
\text { RATIO OL }\end{array}$ & 51.9 & 52.1 & 17.5 & 83.5 & 23.4 & 47.8 & 47.0 & 16.5 & 74.5 & 14.4 & 0.49 & 0.627 \\
\hline $\begin{array}{l}\text { FLEXORS PEAK } \\
\text { TORQUE/BW NOL }\end{array}$ & 108.1 & 92.0 & 42.5 & 267.3 & 72.9 & 97.5 & 107.0 & 42.3 & 134.8 & 27.4 & 0.46 & 0.650 \\
\hline $\begin{array}{l}\text { EXTENSORS PEAK } \\
\text { TORQUE/BW NOL }\end{array}$ & 189.4 & 179.2 & 96.5 & 324.2 & 81.6 & 206.2 & 215.1 & 69.0 & 264.0 & 53.7 & -0.56 & 0.584 \\
\hline $\begin{array}{l}\text { AGON/ANTAG } \\
\text { RATIO NOL }\end{array}$ & 53.8 & 54.5 & 39.3 & 82.4 & 13.6 & 48.9 & 46.3 & 27.1 & 81.6 & 13.4 & 0.80 & 0.436 \\
\hline
\end{tabular}

$O L$ - operated limbs, NOL - non-operated limbs, $\bar{x}$ - arithmetic mean, Me - median, min. - minimum, max. - maximum, SD - standard deviation, $t$-value of $t$-Student test for independent variables/U - value of Mann-Whitney $U$ test, $p$ - level of probability. Source: own study.

5 weeks. Nevertheless, there are also results that indicate an increase in muscle strength of flexors in patients who had been rehabilitated for a longer time.

Analysis should be performed on a larger group of patients in order to determine the effect of the duration of rehabilitation on muscle strength parameters of the knee joint flexors and extensors. In many rehabilitation programmes, and according to the belief of many therapists, there is a need to focus therapeutic actions on strengthening the knee joint flexors after ACL reconstruction, which may be consistent with the results obtained in the presented study (Table 7).

\section{Discussion}

The use of synthetic materials for ACL reconstruction is not as common as the use of autologous and allogeneic transplants. In seeking increasingly better methods of surgical treatment for knee joint ligament injuries, some orthopaedic centres in Poland apply this procedure as an alternative to reimbursed procedures.

The results of short-term studies assessing the functions of the knee joint after use of the LARS method described in literature are promising. The potential benefits of this method are, among others, shorter duration of surgery, possibility to apply early limb loading, and primarily a quicker restoration of the function of the knee joint [10]. Due to the possibility of the introduction of early maximum loading of the operated limb, and carrying out intensive rehabilitation in the first weeks after surgery, the return to occupational and physical activity is quick [8, 19]. Dericks [8] described the result of studies in which the return to full sports activity took place in month 4 after surgery in $61 \%$ of the examined patients, and in month 6 after surgery in $83 \%$ of the patients. This is a considerable difference, compared to the 6-9 months that must elapse to return to full activity after autograft [5]. Investigations of the function of the knee joint during the mean period of 4 years after surgery, enable assessment of the actual functional capabilities of the knee joint after the procedure of ACL reconstruction.

Assessment of muscle strength by isokinetic testing is one of the objective methods of evaluation of the function of the knee joint [13]. The main parameters for comparing the results of the isokinetic test were: percentage of peak torque to body weight (peak torque/BW(\%), and the agon/antago ratio\%, which presents the relation of muscle strength between knee joint flexors and extensors. These parameters demonstrate well the maximum muscle strength of the examined person, and are also applied by other researchers [20].

A normally functioning knee joint is not only the normal strength of individual muscle groups, but also the correct strength ratio between antagonistic muscle groups. An optimum muscle balance provides the achievement of dynamic stabilisation of the joint necessary while undertaking physical activity. The distribution of muscle strength between two extremities is also important. This is manifested mainly while performing complex motor activities, and a deficiency of strength between knee joint extensors or flexors exceeding $15 \%$ may be the cause of more frequent injuries [16].

While assessing the muscle strength of individual functional groups, considering the results obtained in the group of healthy patients, it should be presumed that it was normal. However, analysis of the isokinetic assessment of healthy limbs and those operated on using the LARS method showed a statistically signifi- 
cant difference in the strength of flexor and extensor muscles, to the benefit of the healthy limb. In the study by Gao et al. [21], within the period of 3-5 years after ACL surgery performed using the LARS method, no differences in muscle strength were observed between the limbs. Nevertheless, these patients had undergone a 6-month rehabilitation programme, which ended with the return to physical activity [21]. Macaulay et al [22] presented results by many researchers [23-25] and compared muscle strength in patients treated using flexor tendons and knee cap ligaments. These researchers did not observe any difference between the strength of knee joint flexors and extensors according to the type of graft applied. However, these studies did not cover the comparison of muscle strength between healthy and operated limbs.

In the group of patients in the study, the duration of rehabilitation was from 2 to 4 weeks in $40 \%$ of patients, and more than 5 weeks in $60 \%$ of patients. In the group of patients rehabilitated for longer than 5 weeks, there were 2 patients in whom rehabilitation lasted until month 4 after surgical procedure. The guidelines by authors regarding rehabilitation in patients treated using the LARS method specify the possibility to return to running training within the period of 3-4 months, and the return to full activity in months 4-6 after surgery. For this period, the rehabilitation programme should be continued [10]. In our own study, no differences in muscle strength were observed according to the time of rehabilitation of patients. It seems that in the examined group of patients the rehabilitation time was insufficient.

The subsequent element of the study was evaluation of the effect of age on the strength capabilities of the knee joint muscles. Injury to the cruciate ligaments of the knee joint concerns, to a great extent, young, physically active persons aged 15-25 years, and $50 \%$ of injuries concern individuals aged 15-19 years [26, 27]. The mean age in the group of patients treated using the LARS method was higher, and was approximately 34 years. However, increasingly often knee joint ligament injuries concern adults aged 30-40 years, or even $40-50$ years [28]. Certainly, the health-promoting lifestyle in fashion, which is frequently related with undertaking physical activity by persons not prepared for this type of effort, exerts an effect on the present state of affairs. The age difference within the range of 13 years, which occurred in the examined group of patients, had no effect on the results of muscle strength obtained.

\section{Conclusions}

Despite muscle strength deficit in the operated limb in patients treated using the LARS method, the strength of flexors and extensors was on the same level as the examined healthy population. The duration of rehabilitation was too short to assess the effect of the type of this rehabilitation on muscle strength parameters of the knee joint flexors and extensors. In order to determine the effect of the selected variables on muscle strength parameters, studies should be conducted in a larger population sample.

\section{Conflict of interest}

The authors declare no conflict of interest.

\section{References}

1. Widuchowski J, Widuchowski W, Paściak M. Artroskopia stawu kolanowego - historia i teraźniejszość. Wiad Lek 2005; 58: 111-115.

2. Nagraba Ł, Okrzeja A, Mitek T. Uszkodzenia więzadła krzyżowego przedniego u sportowców. Artroskopia i Chirurgia Stawów 2011; 7: 11-17.

3. Chambat P. ACL tear. Orthop Traumatol Surg Res 2013; 99: 43-52.

4. Abrams GD, Harris JD, Gupta AK, McCormick FM, Bush Joseph ChA, Verma AA, et al. Functional performance testing after anterior cruciate ligament reconstruction a systematic review. Orthop J Sports Med 2014;1: 1-10.

5. Śmigielski R, Chomicki-Bindas P. Rekonstrukcja więzadła krzyżowego przedniego z użyciem ścięgna mięśnia półścięgnistego i smukłego. Acta Clin 2002; 2: 33-39.

6. Barber-Westin SD, Noyes FR. Factors used to determine return to unrestricted sports activities after anterior cruciate ligament reconstruction arthroscopy. J Arthrosc Relat Surg 2011; 21: 1697-1705.

7. Zaffagnini S, Grassi A, Muccioli GM, Tsapralis K, Ricci M, Bragonzoni L, Della VS, Marcacci M. Return to sport after anterior cruciate ligament reconstruction in professional soccer players. Knee 2014; 21: 731-735.

8. Dericks G. Ligament advanced reinforcement system anterior cruciate ligament reconstruction. Oper Tech Sports Med 1995; 3: 187-205.

9. Shaerf D, Pastides P, Sarraf K, Willis-Owen CA. Anterior cruciate ligament reconstruction best practice: a review of graf choice. World J Orthop 2014; 5: 23-29.

10. Machotka Z, Scarborough I, Duncan W, Kumar S, Perraton L. Anterior cruciate ligament repair with LARS a systematic review. Sports Med Arthrosc Rehabil Ther Technol 2010; 2: 29-39.

11. Abbey C. Villwock M, Wojtys EM, Palmieri-Smith RM. Lower extremity muscle strength after anterior cruciate ligament injury and reconstruction. J Athl Training 2013; 5: 610-620.

12. Riemann BL, Lephart SM. The sensorimotor system. Part II: the role of proprioception in motor control and functional joint stability. J Athl Train 2002; 37: 80-84.

13. Chmielewski TL, Rudolph KS, Snyder ML. Development of dynamic knee stability after acute ACL injury. J Electromyogr Kinesiol 2002; 12: 267-274.

14. Yanagawa T, Shelburne K, Serpas F, Pandy M. Effect of hamstrings muscle action on stability of the ACL-deficient knee in isokinetic extension exercise. Clin Biomech 2002; 17: 705-712.

15. Wilkerson G, Colston M, Short N, Neal KL, Hoewischer PE, Pixley JJ. Neuromuscular changes in female collegiate athletes resulting from a plyometric jump training program. J Athl Train 2004; 39: 17-23. 
16. Grygorowicz M, Głowacka A, Wiernicka M, Kamińska E. Kompleksowa ocena fizjoterapeutyczna podstawą profilaktyki pierwotnej urazów sportowych. Nowiny Lekarskie 2010; 79: 240-244.

17. Davies G. A Compendium of Isokinetics in Clinical Usage and Rehabilitation Techniques. Publishers 1992.

18. Rzepka R, Grygorowicz M. Obiektywna ocena w warunkach izokinetycznych w medycynie i sporcie - jej przydatność i zastosowanie. Rehabil Prakt 2007; 4: 14-17.

19. Mascarenhas R, MacDonald PB. Anterior cruciate ligament reconstruction: a look at prosthetics - past, present and possible future. Mcgill J Med 2008; 11: 29-37.

20. Baltaci G, Yilmaz G, Atay AO. The outcomes of anterior cruciate ligament reconstructed and rehabilitated knees versus healthy knees: a functional comparison. Acta Orthop Traumatol Turc 2012; 46: 186-195.

21. Gao K, Chen S, Wang L, Zhang W, Kang Y, Dong Q Zhou H, Li L. Anterior cruciate ligament reconstruction with LARS artificial ligament: a multicenter study with 3to 5-year follow-up. Arthroscopy 2010; 26: 515-523.

22. Macaulay AA, Dean C, Perfetti C, Levine WN. Anterior cruciate ligament graft choices. Sports Health 2012; 4: 63-68.

23. Ageberg E, Roos HP, Silbernagel KG, Thomee R, Roos EM. Knee extension and flexion muscle power after anterior cruciate ligament reconstruction with patellar tendon graft or hamstring tendons graft: a cross-sectional comparison 3 years post surgery. Knee Surg Sports Traumatol Arthrosc 2009; 17: 162-169.

24. Taylor DC, DeBerardino TM, Nelson BJ, Duffey M, Tenuta J, Stoneman PD, Sturdivant RX, Mountcastle S. Patellar tendon versus hamstring tendon autografts for anterior cruciate ligament reconstruction: a randomized controlled trial using similar femoral and tibial fixation methods. Am J Sports Med 2009; 37: 1946-1957.

25. Spindler KP, Kuhn JE, Freedman KB, Matthews CE, Dittus RS, Harrell FE. Anterior cruciate ligament reconstruction autograft choice: bone-tendon-bone versus hamstring: does it really matter? A systematic review. Am J Sports Med 2004; 32: 1986-1995.

26. Vavken P, Murray M. Treating anterior cruciate ligament tears in skeletally immature. Arthroscopy 2011; 27: 704-716.

27. Murray M, Vavken P, Fleming B. The ACL Handbook: Knee Biology, Mechanics, and Treatment. Springer Science and Buisiness Media, New York 2013; 1: 3-17.

28. Collins JE, Katz JN, Donnell-Fink AL, Martin SD, Losina E. Cumulative incidence of ACL reconstruction after ACL injury in adults: role of age, sex and race. Am J Sports Med 2013; 41: 544-549.

\section{Address for correspondence:}

\section{Jędrzej Płocki}

Department of Rehabilitation

Holy Family Specialist Hospital

Rudna Mała 600, 36-060 Głogów Młp., Poland

Phone: +48 781529464

E-mail: jplocki@gazeta.pl 